\title{
THE TRANSITION OF MALAY WOMEN'S ROLE AND CONTRIBUTION IN THE EARLY 20TH CENTURY
}

\author{
Arba'iyah Mohd Noor*
}

\begin{abstract}
This article discusses the transition of Malay Women's role and contribution in the early $20^{\text {th }}$ century. It will unearth the awakening of the $20^{\text {th }}$ century Malay women towards their education. The chronology will start with the introduction of the Malay women before the $20^{\text {th }}$ century and the causes that triggered their consciousness toward the need for education. Between 1900 and 1930s, the Malays were more acceptable towards the education system initiated by the British. After the 1930s, they became more aware of the importance of education for their children, including their daughters. Other issues to be discussed are the changing role or position of women and their contributions to the era in political, economic and social aspects. The methodology of this research is more on qualitative method by using historical approach. The findings show that through education, the society has been able to change women's role compared to the past. The biggest accomplishment was on the status of the Malay women with the highly educated ones being given the trust to play more significant roles in politics, economy and social aspects.
\end{abstract}

Keywords: Malay Women, Educations, Politics, Economy, Social Aspects

\section{Introduction}

Women in ancient times in various civilizations were viewed as inferior. The description of women was reflective of the nature of women as poor individuals, less able to determine their own life or fate and often victimized by others' self-interests. However, the female social status had improved and elevated since the arrival of Islam. The tasks of empowering women were divided among the men and women by taking into consideration the natural physical ability granted by Allah. This was due to the previous societal system that required more physical endurance from the male group. Men were the breadwinners of their families whereas the women handled the domestic affairs.

There were few books written and discussed by scholars and writers on Malay Muslim women in Malaysia such as Lenore Manderson, Women, Politics and Change: The Kaum Ibu UMNO, Malaysia, 1945-1972, Jamilah Ariffin, Women and Development in Malaysia, 1992 and Virginia H. Dancz, Women and Party Politics in Peninsular Malaya. However, previous studies have discussed the role of traditional women in general and further emphasized their position in some areas after the World War II. This article aims to discuss the transition of Malay women's positions, roles and their contributions in the early $20^{\text {th }}$ century in politics, economy and social aspects through historical perspective.

The sources of this article can be divided into five categories. First, the Malay manuscripts covering various aspects of the women in traditional periods such as the Malay Annals (Sejarah Melayu), Bustan al-Salatin, Riwayat Kelantan, Hikayat Abdullah and Salasilah Sultan Omar. Second, information was derived from some records or files which were written by British such as Annual Reports of Selangor, Perak, Terengganu and Negeri Sembilan in the early $20^{\text {th }}$ century. Third, another source of information came from a compilation of newspaper and magazine on various issues involving Malay women in the $20^{\text {th }}$ century such as Bahtera, Warta Malaya, Utusan Zaman, Majlis, Bulan Melay, Kenchana and Cenderamata. Fourth, an interview with Tan Sri Aishah Ghani, former Minister in 1970s which was held on the $27^{\text {th }}$ January 2006 at Kampung Baru Kuala Lumpur. All first four categories are primary sources and the fifth one consists of some secondary sources such as books and articles as additional materials to complete the study.

\footnotetext{
* Arba'iyah Mohd Noor (PhD), Senior Lecturer, History Department, Faculty of Arts and Human Sciences, University of Malaya, Malaysia. Email: arbaiyah@um.edu.my.
} 


\section{The Portrayal of Traditional Malay Women through Historical Works}

In the Malay world, the role and contribution of traditional women may be small compared to men. This is because their roles were less emphasized as compared to the opposite gender. Based on the previous historical works, their positions included being the spouses to the husbands, royal concubines, head of the country or the king and even victims of the situation because they have to meet the needs of those in power. However, all of the said responsibilities were more related to the palace elite women.

In general, there were many written historical works that portrayed women as the weaker gender and commonly became victims to inconsiderate few. Women were also regarded as the prized possession in preventing confrontation among the ministers. For example, Sultan Muzaffar Shah (1446-1456) was willing to divorce his wife named Tun Kudu, who was the eldest daughter of Bendahara Seri Wak Raja, Tun Perpatih Sedang to prevent conflict between Seri Nara Diraja Tun Ali bin Baginda Mani Purindan with Paduka Raja Tun Perak. The two reconciled after Seri Nara Diraja married Tun Kudu, the sister of Tun Perak. ${ }^{1}$ In this picture, Tun Kudu rescued the situation from worsen by sacrificing herself to ensure the country's political stability.

More often than not, women were presented to someone as a symbol of appreciation. An example would be when the act was meant to gratify the efforts made by a Muslim scholar of Pasai named Makhdum Mua who was appointed by the Sultan of Pasai to elaborate and analyse the issue of the inhabitants of hell and heaven mentioned in the book of Durr al-Manzum. Durr al-Manzum means Mutiara Terkarang or Seuntai Mutiara: it was a popular book of tasawwuf in Melaka during the reign of Sultan Mansur Shah. This work was divided into three sections with the first debated on the Divine Essence (Zat) of Allah (God). The second included the Divine Attribute (Sifat) of Allah (God) and the last commented on the Action ( $A f^{\prime} a l$ ) of Allah (God). Then, Makhdum Mua was rewarded with seven grams of gold and two women, Dang Bunga and Dang Bibah by Tun Bija Wangsa as entrusted by Sultan Mansur Shah (1459-1477). ${ }^{2}$

Women were assumed to be uncapable of planning their own lives and future. It was evidential in the case of Tun Fatimah, the daughter of Bendahara Tun Mutahir who married Sultan Mahmud Shah after her husband Tun Ali and his entire family except Tun Hamzah were sentenced to death without a proper trial due to slanderous accusation done by Si Kitul and Raja Mendaliar. Si Kitul and Raja Mendaliar created a slanderous accusation by claiming that the Bendahara made a pact with Nina Sura Dewana to murder Raja Mendaliar. Raja Mendaliar however, informed the news to Laksamana Khoja Hassan and together told the sultan. Without any investigation and revenge towards the Bendahara for presenting Tun Fatimah to the sultan before marrying Tun Ali, Sultan Mahmud commanded Tun Sura Diraja dan Tun Indera Segara to annihilate the Bendahara and his family. ${ }^{3}$

Furthermore, some women were subjected to sexual needs of those in power. For example, the wife of Tun Biajid was raped by Sultan Mahmud Shah when her husband was away to Merba. Tun Biajid who was the son of Laksamana Hang Tuah, went to Merba which was under his supervision. After knowing that his wife was molested by the sultan, he divorced her and resigned from his post for the sultan. To ease his rage, Sultan Mahmud presented him with his mistress, Tun Iram Sendari who later became his wife. Because of that event, Tun Biajid refused to attend any royal functions and was said to leave Melaka. $^{4}$

Similar fate befell Tun Dewi who was forced to live together with Sultan Mahmud and Tun Teja (daughter of Bendahara Pahang, Seri Amar Bangsa Diraja) who was the fiancee of Sultan Abdul Jamal of Pahang. She was also taken by Sultan Mahmud to be his wife. Hang Nadim was sent to Pahang by Sultan Mahmud in order to get Tun Teja. He paid an old maid of Bendahara Pahang with a lot of gold and clothing to persuade Tun Teja to agree and follow him to Melaka to become the wife of Sultan

\footnotetext{
${ }^{1}$ Tun Kudu was the eldest daughter of Bendahara Seri Wak Raja, Tun Perpatih Sedang. A.Samad Ahmad (romanized) (1996), Sulalatus Salatin-Sejarah Melayu, Kuala Lumpur: Dewan Bahasa dan Pustaka, p. 87.

${ }^{2}$ Shafie Abu Bakar (1989), "Kitab al-Durr al-Manzum and Kitab al-Luma' Sebagai Pancaran Budaya Ilmu di Melaka: Permasalahan dan Pengaruh Lanjutannya," Working paper of International Conference of Malay Studies. University of Malaya, Kuala Lumpur, pp. 7-8. See also Wan Muhammad Wan Ali (1973), Suntingan dan Anotasi Sebuah Kitab Tasawwuf Melayu Kurun Ketiga Belas Hijrah/ Kedelapan Belas Masihi: ad-Durru'n-Nafis, MA Thesis, Institute of Language, Literature and Culture. Kuala Lumpur: National University of Malaysia,.

${ }^{3}$ A. Samad Ahmad (1996), Sulalatus Salatin: Sejarah Melayu,pp. 255-259.

${ }^{4}$ A. Samad Ahmad (1996), Sulalatus Salatin: Sejarah Melayu, p 193.
} 
Mahmud Shah. With his bravery, Sultan Mahmud granted him a lot of awards including Nakhoda Saiyid Ahmad who loaned his ship to him on his sail back to Melaka. ${ }^{5}$ In these scenario, women seemed to have no right to choose and determine their rights but surrender for the benefit of others, as stated by Freud and quoted by Bardwick: "[...] the world was clearly dominated by men and he took the phallocentric viewpoint, emphasizing the penis as the source of power". 6

Although some women in the traditional era were described as the weaker gender or can be classified as very passive, there were certain women who were very brave, even capable of being heads of state. An example was mentioned in the Bustan al-Salatin that dictated the reign of Queen Safiyatuddin (the wife of Sultan Iskandar Thani) after the demise of her husband as the Sultan of Acheh. She was a wise and courageous sultan and during her 35 years of ruling, Acheh remained peaceful and prosperous. ${ }^{7}$ Besides, there were other women who were also rulers of the kingdom. For example, Che Siti Wan Kembang and Puteri Saadong (Jembal origin) were crowned the king of Kelantan as portrayed by the Riwayat Kelantan and Wan Seri Bini was made the king of Bintan as depicted through Sejarah Melayu. ${ }^{8}$

There were certain palace women who were uninvolved in the governing affairs but were highly influential in the country. Even though their existence was less acknowledged, their influence in every decision made by the ruler was highly significant. The political affairs during the traditional period that required their involvement was the selection of the new ruler to replace the previous sultan (king). For instance, during the selection of the next king of Johor, Tun Fatimah was the one who determined the rights and assurance of her unborn baby to sit on the ruling of the next throne. With the agreement from Sultan Mahmud Shah, it was finally decided that Raja Ali (the son of Sultan Mahmud and Tun Fatimah) was hailed as the sultan of Johor with the title of Sultan Alauddin Riayat Shah I (1528-1564) to replace his deceased father who died in Kampar. This incident caused Raja Muzaffar, the first son of Sultan Mahmud to isolate himself by taking his family with him to Kelang. They were later brought to Perak by the people of Manjong and honor him as the first Sultan (king) of Perak known as Sultan Muzaffar Shah. ${ }^{9}$ This situation indicated that Tun Fatimah was a clever, assertive women and she tried to manipulate the patriarchal power, as stated by Phelps and Austin, 'There seem to be two major aspects of personal power for women: methods of getting it and keeping it and attitudes about having it and using it ${ }^{10}{ }^{10}$

In general, even though there were many women who became victims of the unfortunate situation, several women from the elite group of the society were directly and indirectly involved in the government. In fact, they could even be considered as early pioneers involved in government politics.

\section{Women in the British Era}

In the late 19th century, the British new ruling strategy to monopolize Malaya gave an impact toward the Malay political influences in politics. The establishment of the Federated Malay States in 1896 reaffirmed the British action in interfering with the Federated Malay States especially in controlling the economy and tax. ${ }^{11}$ The power of the sultan (king)and the ministers were taken over by the British officers. The ruling rights of the Malays that were denied caused isolation from any form of governing of the country. To add to the agony was the arrival of the Chinese and Indians to Malaya as well as the divide and rule system applied by the British had totally caused the Malay political system to weaken. The slow and steady discarding of the Malays in the ruling system had, in a way, reduced the chance for local women to be seriously active in politics like the European women. During the colonial era, only a few written sources on women's involvement in politics, administration and government were available but the elite together with the middle-class group's living that was inclusive of education and healthcare were improved.

\footnotetext{
5 A. Samad Ahmad (1996), Sulalatus Salatin: Sejarah Melayu, pp. 193-194, 224-231.

${ }^{6}$ J. M. Bardwick (1971), Psychology of Women: A Study Of Bio-Cultural Conflicts, New York: Harper and Row, p. 5.

${ }^{7}$ Jelani Harun (ed.) (2004), Bustan al-Salatin, Kuala Lumpur: Dewan Bahasa dan Pustaka, pp. 368-377.

${ }^{8}$ Asaad Shukri Hj. Muda (n.d.), Riwayat Kelantan, Manuscript was transliterated by Zahir Ahmad; Abdul Rahman Haji Ismail (romanized)

(1998), Sejarah Melayu-The Malay Annals, MS. Raffles No.18, Kuala Lumpur: MBRAS, p.89.

${ }_{9}^{9}$ Abdul Rahman Haji Ismail (romanized) (1998), Sejarah Melayu-The Malay Annals, pp. 298-299.

${ }^{10}$ S. Phelps \& N. Austin (1975), The Assertive Woman, California: IMPACT, p. 56.

${ }^{11}$ N.J.Ryan (1959), Malaya Through Four Centuries an Anthology 1500-1900, London: Oxford University Press, p. 145.
} 
The Malay women's movement toward development was very slow in the early 1900 as compared to other races in Malaya since disapprovals came from their families and the society. They still had their conventional beliefs that women were only accepted as just male assistants who diligently obey any commands given by the head of the family. Therefore, for some parents, the girls just needed to stay at home, learned a little about household as they would eventually became housewives like their mothers in the yesteryears who were capable of educating and taking care of the family even without substantial education. ${ }^{12}$ They were only given attention in terms of basic education, as well as being slightly educated in Malay language. This was due to the customs of the Malays who banned their young women to go out freely.

It was during the 20th century that this phenomenon changed due to women's exposure to formal education like other male children. There were several factors that encouraged parents to educate their - young women and send all their children to school, which eventually caused an increase in the number of girls attending formal schools. First, there were also a handful of intellectuals who were opened minded and accepted the fact that the Malay women had the right to improve their living standards. They agreed with the idea that Malay women needed to excel in politics and be at par with the Malay men. ${ }^{13}$ These men's openness was the result of a string of exposure to the education they had received. Some of them were highly educated Malays like Zainal Abidin bin Ahmad (Za'ba), who was partly educated in the Middle East like Syed Syeikh al-Hadi. ${ }^{14}$ Hence, they were constantly raising awareness for women to move forward, strengthen political organizations and bring change to society. Those days, only a handful of Malay women managed to obtain higher level of education with an exception of the Malay elite.

Second, there were many recommendations in the newspapers and magazines about the importance of education among Malay children, either male or female. Issues concerning the advancement of Malay women became the main headlines in the newspapers and local magazines in Malaya such as Saudara, Majlis, al-Imam, al-Hikmah, Majalah Guru, Utusan Zaman, Bahtera, Bulan Melayu etc. For instance, al-Imam was emphasizing the benefits and importance of education to children including girls for the progress of the Malays in the future. ${ }^{15}$ In addition, the authors of the newspaper and the magazine also criticized some practices that restricted Malay women to move forward. They felt these practices were no longer relevant in the 20th century. Most of the newspapers and magazines write ups between the 1920s and 1940s urged the women to have the awareness in the aspect of development since they were seen to be behind as compared to the other races.

Third, the teachers also encouraged the students to continue their studies to success. For example, Kontik Kamariah binti Ahmad, a visiting teacher who came to several schools in Selangor in 1933, always encouraged students to succeed in education. ${ }^{16}$ In the same year, a visiting teacher, Mohd. Yusof $\mathrm{Ahmad}^{17}$ visited several schools in Selangor to identify good students to further their studies in English schools after completing Fifth Class. ${ }^{18}$ There were a lot of efforts that teachers had to make because the number of Malay pupils in school especially English schools were still lower than that of other pupils.

\footnotetext{
12 Utusan Zaman, (31st December 1939).

${ }^{13}$ Utusan Zaman (17th December 1939).

${ }^{14}$ Syed Sheikh al-Hadi was one of the leading figures in Kaum Muda. He received religious education in Pulau Penyengat and in the Middle East. He was a journalist, reformist and demanded equal rights for women. There were many writings that criticize traditional practices against girls like Kitab Alam Perempuan, Faridah Hanom etc. See Adibah Sulaiman et. al. (2011), "Syed Shaykh Ahmad Alhady: A Religious Education Reformist in the Late 19 and Early 20 Century," Middle-East Journal of Scientific Research, Vol. 7, Special Issue of Diversity of Knowledge on Middle East, pp. 14-21.

consisted of Middle Eastern - educated scholars with Pan-Islamic sentiment. Talib Samat (1992), Syed Syeikh al-hadi: Sasterawan Progresif Melayu, Kuala Lumpur: Dewan Bahasa dan Pustaka, pp. 1-6.

${ }^{15}$ Al-Imam, Issue 1, Vol. 6, 18 December 1906. See also al-Imam, Issue 6, 6 December 1906. Zaiton Ghani (1985), "Wanita Melayu Dalam Politik 1946-1948," in Khoo Kay Kim (ed.), Sejarah Masyarakat Melayu Moden, Kuala Lumpur: Jabatan Penerbitan Universiti Malaya, pp. $210-211$.

${ }^{16}$ Aishah Ghani, Memoir Seorang Pejuang, p. 4.

${ }^{17} \mathrm{He}$ was the younger brother of Za'ba. He received his education as early as seven years, when a school was established in Batu Kikir. Abdullah Hussain \& Khalid M. Hussain (2000), Pendeta Za'ba dalam Kenangan, Kuala Lumpur: Dewan Bahasa dan Pustaka, p.22.

${ }^{18}$ Aishah Ghani, Memoir Seorang Pejuang, p. 5.
} 
The Transition of Malay Women's Role and Contribution in the Early 20th Century

Table 1. Total of the female pupils enrolled in English schools in 1928 and 1929

\begin{tabular}{|l|c|c|c|c|c|c|}
\hline \multirow{2}{*}{ No. } & \multicolumn{3}{|c|}{$\mathbf{1 9 2 8}$} & \multicolumn{3}{c|}{$\mathbf{1 9 2 9}$} \\
\cline { 2 - 7 } & $\begin{array}{c}\text { Malay } \\
\text { States }\end{array}$ & $\begin{array}{c}\text { Straits } \\
\text { Settlements }\end{array}$ & Total & $\begin{array}{c}\text { Malay } \\
\text { States }\end{array}$ & $\begin{array}{c}\text { Straits } \\
\text { Settlements }\end{array}$ & Total \\
\hline Malay & 109 & 80 & 189 & 155 & 93 & 248 \\
\hline European & 481 & 1,421 & 1,902 & 467 & 1,474 & 1,941 \\
\hline Chinese & 2,087 & 3,843 & 5,930 & 2,485 & 4,110 & 6,595 \\
\hline Indian & 916 & 349 & 1,265 & 888 & 431 & 1,430 \\
\hline Others & 166 & 197 & 363 & 190 & 197 & 387 \\
\hline Total & $\mathbf{3 , 7 5 9}$ & $\mathbf{5 , 8 9 0}$ & $\mathbf{9 , 6 4 9}$ & $\mathbf{4 , 2 9 7}$ & $\mathbf{6 , 3 0 5}$ & $\mathbf{1 0 , 6 0 1}$ \\
\hline
\end{tabular}

Sources: Modified data from Bulan Melayu (June 1930), p. 11 and Bulan Melayu (January 1930), p. 259.

The data in 1928 and 1929 show the lowest number of Malay female pupils who enrolled the English schools compared to European, Chinese, Indians female pupils. The importance of education among Malay women continued to be discussed by the mass media in the 1930s. The purpose of education was to enable them to educate their children more effectively because mothers are the first teachers of children. Hajjah Zainon Sulaiman (Ibu Zain) ${ }^{19}$ has suggested Malay female students to join the Girl Guides to build self-confidence in order to compete with other nations. ${ }^{20}$

Through the encouragement of various parties, awareness was inculcated among parents to send their daughters to either Malay or English school. The number of female students increased from year to year and there were even female pupils enrolled in male schools because of the lack of female schools. ${ }^{21}$ These educated middle class women eventually became involved in community activities. Their mission was to improve opportunities for Malays to be involved in every aspect of life and defended their nation and country. These urges finally resulted in the involvement of the middle-class women in societies and movements that were established to elevate the chances for the Malays to be involved in politics, economy and education.

\section{The Changes in Women's Contribution in Politics}

In general, the role of women was varied from the early days to the early 20th century. They were the wives and mothers who ran the household, partly as heads of state and also played a role in deciding the future of the king. Women's nature which was supposed to be gentle, was one of the barriers to their involvement in external affairs, especially politics. Besides, most parents did not encourage their daughters to be exposed to political matters. This was because by exposing Malay women to politics, they would contribute to the decrease in the eastern values and cultures. ${ }^{22}$ The men on the other hand feared for their rights to be overshadowed by the women, their pride at stake as well as requesting for equality. ${ }^{23}$ After receiving education, the women became more conscious of their rights and functions in all aspects. This factor contributed to the later involvement of the Malay women in issues related to politics, administration and social.

The involvement of women in group activities has been seen as one of the factors that motivates women to engage in various activities. Those who are engaged in this activity have a social agenda and this eventually becomes the catalyst for the establishment of Malay women organization. The early organization established in Malaya was Young Women's Christian Association (YWCA) in 1875 by a

\footnotetext{
${ }^{19}$ Ibu Zain who was born in Nyalas, Melaka was the daughter of Munsyi Sulaiman. She attended Methodist Girls School, Tengkera (1909 1912) followed by Tengkera School (1913 - 1915) until she graduated from Junior Cambridge. In 1921, she became a teacher at Maharani Girls' School in Muar, where in 1924 she became headmistress. She was involved in many activities and wrote many columns in newspapers and magazines. Her writing has given a lot of awareness to women in the 1930s. She was remembered as an advocater of education for girls through her writings in Majalah Guru or Bulan Melayu. Virginia H. Dancz (1987), Women and Party Politics in Peninsular Malaysia, Singapura: Oxford University Press, p. 170.

${ }^{20}$ Bahtera (26 April 1932).

${ }^{21}$ Annual Report on Education in Straits Settlement and the Federated Malay States 1937, p. 54.

${ }^{22}$ Majlis, (1 ${ }^{\text {st }}$ December 1934).

${ }^{23}$ Utusan Zaman, (21st January 1940).
} 
Sophia Cook. Its early agenda was focused on Christianity but later, the movement expanded to a wider scope. It was evident during a convention in Singapore in March 1938, at which YWCA stood firm in defending women's position in the society which was based on their own abilities. Even though the YWCA was generally populated by the Chinese and European girls, there were several Malay women who joined them by organizing short-hand classes, typing classes, the Malay language, French classes, sewing, cooking and first aid lessons. In fact, the YWCA carried out significant activities such as establishing a nursing home for women laborers in $1938 .{ }^{24}$

In 1917, a women's organization known as the Pandu Puteri (Girl Guides) was formed as a result of efforts made by Miss Gertrude Ballard. As a schoolteacher at the Methodist Girls' School in Kuala Lumpur, she along with Miss Mable Marsh introduced the Girl Guides unit at the school and later led the establishment of the Girl Guides in Kuala Lumpur ran by the YWCA. This organization was able to attract Malay pupils in Malaya to join the organizations. ${ }^{25}$

Besides, some educated Malay women were involved in the teachers' organization. For example, Kesatuan Guru Malaya (Malaya Teachers' Union) was the first Malay women union established by Hajjah Zainun Sulaiman in $1929 .{ }^{26}$ She even organized journals on Majalah Guru and Bulan Melayu by debating on the issues related to monogamy, children educational methods and jobs for men and women as well as setting up and administrating government schools for the entire Johore state. This organization inspired the spirit of the Malay mothers to be actively participative. On the 20th January 1930, the Kaum Ibu (Women Organization) of Johor Bharu held a discussion followed by a convention on the 25th April 1930 at Batu Pahat. The two meetings debated on the necessity of the establishment of Persekutuan Perempuan Melayu-Johor (Malay-Johore Women Organization). The outcome has led to the establishment of the Persekutuan Perempuan Melayu-Johor in $1930 .{ }^{27}$ Several other organizations were later established such as the teachers in Melaka in 1938 with the aim of gathering the women in a cooperative bond in defending the religious dignity and race.

The patriotic consciousness in Malaya which began at the end of the 19th century witnessed the Malay women involvement in politics was rather slow compared to men. Even in the 20th century, the women were not brave enough to come forward and involved in politics. For example, Kesatuan Melayu Muda (Young Malay Union) that was established by Ibrahim Haji Yaakob in 1938, he first national organization in the political framework, is a clear evidence of the non-woman dominant fighter against the colonizer. This party was considered to be a party that was national in character since it combined the entire members of Malaya that emphasized war against the colonizer for the development of the Malays. ${ }^{28}$

In 1940s, the national movement that was at first individualistic in nature gradually headed towards unity with the scholars' role in uniting the Malay societies. The first and main issue highlighted by these organizations was to instill consciousness on the idea of patriotism amongst the Malays together with the matter regarding to the Malay language in the administrative activities. Like the men, the women became steadily engaged in various organizations for their development in all aspects of lives.

With regards to this development, there were several organizations established in this era. For example, Kesatuan Melayu Singapura (KMS) or Malay Union of Singapore established a women's wing in 1940, followed by the establishment of the Persatuan Wanita Melayu Terhormat Johor. The association was organized by Azizah Jaafar (Dato' Onn's sister) and supported by the wife of the Chief Minister of Johor. The purpose of the establishment was to eradicate illiteracy among adult women, providing domestic skills such as sewing, cooking and so on. ${ }^{29}$ According to Dancz, after the Japanese left, Ibu Zain established Kumpulan Ibu Sepakat (KIS) in Johor and soon after, Dato' Onn requested for KIS to be one of the components of the Pergerakan Melayu Semenanjung (The Movement of the Malay

\footnotetext{
${ }^{24}$ Lenore Manderson (1981), Wanita, Politik dan Perubahan Pergerakan Kaum Ibu UMNO, Malaysia, 1945-1972, Samsudin Jaapar (trans.), Kuala Lumpur: Fajar Bakti, p. 91.

${ }^{25}$ Ab. Halim Rahim \& Balkis Wan Daud (1992), Pandu Puteri Malaysia, Kuala Lumpur: Dewan Bahasa dan Pustaka, p.8.

${ }^{26}$ Lenore Manderson (1981), Wanita, Politik dan Perubahan, p. 76.

${ }^{27}$ Bulan Melayu (June 1930), pp. 6-9.

${ }^{28}$ Ramlah Adam (1994), Ahmad Boestamam: Satu Biografi Politik, Kuala Lumpur: Dewan Bahasa dan Pustaka, 1994, p. 21.

${ }^{29}$ Lenore Manderson (1981), Wanita, Politik dan Perubahan, p.77.
} 
Peninsular). ${ }^{30}$ The existence of these women's organizations was an early step in their involvement in politics and became active after World War II.

The women's participation in politics officially began after their enrollment in several national organizations such as the Angkatan Wanita Sedar (AWAS) as the women's wing of the Malay Nationalist Party (Parti Kebangsaan Melayu Malaya (PKMM) and the United Malays National Organisation (UMNO) through The Kaum Ibu UMNO (Women Association of UMNO). After the failure of administration designed by the Malayan Union, the people of Malaya at that time especially the Malay women became united in protecting the country from being invaded and claimed to have their own government. It became the starting point for them to join forces with the men in achieving the same goal together in the field of politics.

Before the establishment of AWAS, the PKMM women's wing leader was Aishah binti Ghani. ${ }^{31}$ After Aishah Ghani's intention of stepping down from the PKMM, AWAS was formed in Febuary 1946 and Shamsiah binti Fakeh was asked to take over her post as the leader of AWAS. Shamsiah Fakeh who originated from Kuala Pilah was a friend of Aishah Ghani while studying at Diniyah Puteri, Padang Panjang Sumatera. AWAS's establishment in the political scene after the war was vital to uplift the spirit of the society's consciousness with regard to women's rights and position. As a women left wing in the PKMM, AWAS became a solid proof of the women's contribution in politics in Malaya. ${ }^{32}$ Amongst those who were involved in AWAS were Raja Perempuan Kelsom Latin, the wife of Sultan of Perak, Shamsiah Fakeh, Zainab Mahmud (AWAS Secretary), Siti Norkiah Mahmud (leader of AWAS Pahang) and many more. All of them believed that with their contribution would attract more women to join the PKMM. This was due to the PKMM which was the first Malay progressive political party formed after the Japanese occupation of Malaya. In fact, their main goal was to achieve full independence for Malaya and to oppose any form of British colonial rule. ${ }^{33}$

During the UMNO's general meeting in 1946, the gathering of Datin Sri Puteh Mariah binti Ibrahim Rashid (a government officer with English education and also a representative of Malay Association of Perak), Zainab binti Abdul Rahman (a representative of Malay Association of Seberang Perai) and Saleha binti Mohd Ali (a representative of Malay Association of Selangor) came up with the idea of establishing a women's movement. Their discussions led to the development of the Women's Department that functioned to assist the women in crisis. This department was expanded to become Pejabat Setiausaha (the Secretary's Office) before it was officially established in 1949 with a new name, Pergerakan Kaum Ibu UMNO (Women Association of UMNO and now known as Women's Wing of UMNO). Their main aim was to encourage the members to play important roles in the general issues as well as the government for the betterment of the Malays in politics and to become their representatives in requesting for their rights in the government. ${ }^{34}$

The women's awareness in politics was officially recognized with the establishment of the Pergerakan Kaum Ibu UMNO on 25th August 1949, three years after the existence of its main body, UMNO. This was due to the UMNO leaders who believed that the women were able to work together with the men to strengthen the party's organization. It was stated by Dato' Onn in his speech "the voice of Kaum Ibu will be as powerful as that of the man-the voice of both will determine the shape of the administration of the country". ${ }^{35}$ The early leader who led the Pergerakan Kaum Ibu UMNO was Puteh Mariah (19461949), Hajjah Zainun binti Sulaiman (1950-1953), Khatijah binti Sidek (1954-1955), and Datin Fatimah

\footnotetext{
${ }^{30}$ Lenore Manderson (1981), Wanita, Politik dan Perubahan, p.77; Virginia H. Dancz (1987), Women and Party Politics in Peninsular Malaysia, p. 170.

${ }^{31}$ CPR.K 17/95, no 1A. Documentary on Aishah Ghani, National Archieve of Malaysia. CPR.V. 22/95. Documentary on Aishah Ghani. National Archieve of Malaysia.

${ }^{32}$ Interview with Tan Sri Aishah Ghani on the 27th January 2006, Kampung Baru Kuala Lumpur. See also Lenore Manderson (1981), Wanita, Politik dan Perubahan Pergerakan Kaum Ibu UMNO, Malaysia, 1945-1972, Samsudin Jaapar (trans.), Kuala Lumpur: Fajar Bakti, p. 83.

${ }^{33}$ Shamsiah Fakeh (2007), Memoir Shamsiah Fakeh: Dari Awas ke Regimen ke-10, Petaling Jaya: SIRD, p. 37. Ishak Saat, "Peranan Wanita dalam Gerakan Kiri”, in Ishak Saat and Nazarudin Zainun (2011), Wanita dan Perjuangan, Batu Pahat: UTHM, p. 10. Mohamed Salleh Lamry (2011), Siti Norkiah Mahmud: Srikandi dari Pahang Utara, Petaling Jaya: SIRD, pp. xii, 45.

${ }^{34}$ Malay Association of Penang was among the first society that established in 1937. It was later followed in September by Malay Association of Perak. The organization of Malay Association of Selangor was held in June 1938. Lenore Manderson (1981), Wanita, Politik dan Perubahan, pp. 58-59. Virginia H. Dancz (1987), Women and Party Politics in Peninsular Malaysia, Singapore: Oxford University Press, p. 169.

${ }^{35}$ Lenore Manderson (1980), Women, Politics and Change : The Kaum Ibu UMNO, Malaysia, 1945-1972 Kuala Lumpur: Oxford University Press, p. 43.
} 
binti Haji Hashim (1956). ${ }^{36}$ This movement intended to educate the women the idea of independence as well as the spirit of patriotism.

The main focus of the Pergerakan Kaum Ibu UMNO was to organize various programmes to amalgamate the Malays to fight against the Malayan Union as well as to elevate the women's role in various fields. There were 36 separate societies inclusive of Women Association of Selangor merged together with UMNO at the end of June 1946 as an effort to fight against the Malayan Union. ${ }^{37}$ They agreed that unity with UMNO movement would indirectly enable the Malay community to be stronger and dynamic as a whole. ${ }^{38}$

During the battle against the Malayan Union in 1946, the Malay women especially the Pergerakan Kaum Ibu UMNO united with the Malay men to thwart the establishment of the Malayan Union. They were very active in societies with social agenda that resulted as the steppingstone to the establishment of the Malay women organization. ${ }^{39}$ The Pergerakan Kaum Ibu organized a home awareness campaign, and encouraged the people to participate in demonstrations against the Malayan Union and others. Those who had previously ignored political affairs dared to participate in debates in uplifting the spirits of women against the Malayan Union. ${ }^{40}$ They did not only participate in the march against the Malayan Union, but also took an active part in expressing their views. ${ }^{41}$ Among those identified were Zaharah Abdullah who also spoke at a rally in Batu Pahat. She was a school teacher who had strongly opposed the Malayan Union. Meanwhile, in Negeri Sembilan, Halimahton along with 120 men held a gathering during the visit of T.S. Adam. On top of that, she had to stop T.S. Adam's car and expressed her opposition to the Malayan Union. ${ }^{42}$

Obviously, through the education received by these Malay women, they were able to change people's lives. They began to establish women's associations and paved the first step for Malay women to engage in small associations and political activities. In fact, these early platforms brought them more actively involved openly after World War II. The involvement of women in politics was important at the time as it brought further advancement among women in various aspects of life afterwards.

\section{Malay Women Contribution to Economic Development}

Women were very economically active since the traditional era. Their involvement was seen as efforts to assist the men to lessen the families' burden. However, their noble acts were unacknowledged by most researchers and historians, including the society at that time with the confusion on the segregation of tasks for the women. This scenario existed due to the exaggerated focus on men's strength as the head of the family who managed the family's economy. On the other hand, women were just a symbol whose main function was to be by men's side. Hence, it is not odd to find it difficult to find any information related to women in the traditional era even as mere fairy tale character.

The traditional Malay women's contribution on economic rights was recognized by the custom (adat) ${ }^{43}$ and Islam $^{44}$ via land ownership. The land was the main source of income in the previous era. Land ownership was indicative of the authority over the family's economy and the local community. Women with lands would manage themselves to raise their families. The widows and second wives were made responsible in managing the families' income even though it was meant to be handled by their husbands. As for the single ladies, their role included taking care of their families especially parents who were getting old. ${ }^{45}$

\footnotetext{
${ }^{36}$ UMNO Malaysia (n.d.), Pergerakan Kaum Ibu UMNO: Sejarah dan Kejayaan-kejayaannya, Kuala Lumpur: Bahagian Penyelidik Ibu Pejabat UMNO Malaysia, p. 1.

${ }^{37}$ UMNO Malaysia (n.d.), Pergerakan Kaum Ibu UMNO, p. 65.

${ }^{38}$ Aishah Ghani (1993), "Peranan Wanita UMNO dalam Politik Kebangsaan," in UMNO Dalam Arus Perdana Politik Kebangsaan, Kuala Lumpur: Mahir Publications, pp. 262-263.

${ }^{39}$ Even though the consciouness toward politics was visible in the turn of 1946, the chronological battle toward the Malayan Union as well as its awareness began years earlier.

${ }^{40}$ Lenore Manderson (1981), Wanita, Politik dan Perubahan, p. 66.

${ }^{41}$ Lenore Manderson, Women in Politics: Change or Continuum? The Case of Malay Women in Peninsular Malaysia, p. 1056.

${ }^{42}$ Ramlah Adam (1978), UMNO Organisasi dan Kegiatan Politik, Kuala Lumpur: Mohd Nawi Book Store, p. 194.

${ }^{43}$ Similar to the Temenggung custom or adat Perpatih, both asserted the same right on land ownership to the Malay women. However, the adat Perpatih emphasized more on the women to become landowners.

${ }^{44}$ Islam outlined the rights on properties to the women based on faraid.

${ }^{45}$ Lenore Manderson (1981), Wanita, Politik dan Perubahan, p. 34.
} 
Generally, most of these Malay women came from the working families. Their main objective was to find an alternative solution in raising big families. This intention forced them to come out and handled easy jobs since they could not rely entirely on the men. The aristocrats and the royal family members did not allow their women to join the work force since their economy was sufficient enough as compared to the local people. They could afford to use maids and staff to assist them managing the domestic affairs and economy. This is proven with a statement made by Abdullah Munsyi on the Malay women in Hikayat Abdullah:

The Malay custom... if you became the wife to the rich, you become more arrogant and lazy... it would be a disgrace if made to work in short or long hours, anything that could cause tiredness to the body,... woke up late in the morning... slept long until evening... those were the advantages of marrying a rich and important man. ${ }^{46}$

Nonetheless, there were also female members of the royal family and individuals who obtained wealth from the businesses that they run. They were involved in trading, owned mines, and contract to collect taxes as well as buying slaves who were in debt. ${ }^{47}$ The emergence of colonialism and the economic changes in Malaya towards the capitalist monopolization however, limited women's involvement in the sector. According to Jamilah Ariffin, the existence of British owned land in Malaya (Torrens Land Law) contributed to the different lifestyles of the traditional Malays. ${ }^{48}$ The women economic activity was also affected. Educated female aristocrat also began to participate in trades and other professions such as nurse, assistant nurse, teacher, midwife and social worker. The less educated women contributed in other fields such as working as telephone operator, short-hand writer and assistant clerk. ${ }^{49}$

In depth analysis concluded that the Malay women had contributed in the domestic affairs of their family, years ago. Muhammad Ibrahim Munsyi wrote in his article on the tasks of daughters in the Malay society in Melaka. From the economy and jobs perspective, the Malay community was seen to be more diligent as stated in Kisah Pelayaran Muhammad Ibrahim Munsyi which was written based from his own analysis and observation;

...seeds sowing, planting, transfering, plaiting, punching, harvesting, brooming, children caring, cooking, sewing, treading, picking, sifting, needing, lifting, cutting, tying, reeling, keeping... hence, their daughters took over their mothers' tasks... as I mentioned earlier ${ }^{50}$

Most female tasks listed by him were related to economy. They included traditional activities such as paddy planting, gardening, creating souvenir such as woven items, embroidery, harvesting crops and trading them as a source of income for their families. In Perak, the women were highly skillful in creating mats and embroidery. ${ }^{51}$

In generally, paddy planting was one of the economic activities carried out by the Malay society. This hereditary activity did not only involve men but also women.

Table 2. Population Engaged in Paddy Cultivation in Malaya, 1911-1957

\begin{tabular}{|l|c|c|c|c|}
\hline Gender & \multicolumn{2}{|c|}{ Male } & \multicolumn{2}{c|}{ Female } \\
\hline Year & Total & Percentage (\%) & Total & Percentage (\%) \\
\hline 1911 & 53795 & 49.1 & 55679 & 50.9 \\
\hline 1921 & 262960 & 55.7 & 209057 & 44.3 \\
\hline 1931 & 242436 & 64.3 & 134368 & 35.7 \\
\hline 1947 & 333261 & 70.8 & 137378 & 29.2 \\
\hline
\end{tabular}

\footnotetext{
${ }^{46}$ Abdullah bin Abdul Kadir Munsyi (1974), Hikayat Abdullah, Kuala Lumpur: Dewan Bahasa dan Pustaka, p. 82.

${ }^{47}$ Lenore Manderson (1981), Wanita, Politik dan Perubahan, p. 36.

48 The British-owned land system witnessed the land as a controlled commodity with the existence registered letter of ownership. Deserted lands will automatically become the government's properties. This situation caused the people of Malaya to continue the tradition of opening new lands for agricultural purposes and residences with permission and registered legally. Jamilah Ariffin (1992), Women and Development in Malaysia, Selangor: Pelanduk Publication, p. 10.

${ }^{49}$ Manderson Lenore (1981), Wanita, Politik dan Perubahan, p.36.

${ }^{50}$ Kisah Pelayaran Muhammad Ibrahim Munsyi, annotated by Mohd Fadzil Othman (1980), Kuala Lumpur: Dewan Bahasa dan Pustaka, pp. 40-41.

${ }^{51}$ Kisah Pelayaran Muhammad Ibrahim Munsyi, p.35.
} 
Table 3. Population Engaged in Fishing in Malaya 1911-1957

\begin{tabular}{|l|c|c|c|c|}
\hline Gender & \multicolumn{2}{|c|}{ Male } & \multicolumn{2}{c|}{ Female } \\
\hline Year & Total & Percentage (\%) & Total & Percentage (\%) \\
\hline 1911 & 6216 & 97.2 & 177 & 2.8 \\
\hline 1921 & 48720 & 95.2 & 2488 & 4.8 \\
\hline 1931 & 53551 & 97.7 & 1268 & 2.3 \\
\hline 1947 & 63588 & 98.5 & 762 & 1.2 \\
\hline
\end{tabular}

Source: Amarjit Kaur (January 1989), “An Historical Analysis of Women's Economic Participation in Development", Paper presented at the Colloquium on Women and Development-Implication for Planning and Population Dynamics, University of Malaya,

Based on the information or data provided by Amarjit Kaur, it is clear that there was female involvement in the paddy planting sector during the colonial period. The increase in the number of women paddy planters in Malaya became a sole proof of the inherited traditional agricultural activity. It was only in the fishery activity that witnessed a decline in the number of fisherwomen for the past 36 years. This was a result of job preferences that differed from the previous years. In 1911, many Kedah women were involved in paddy planting in nine villages such as Kota Star, Padang Terap, Yan, Baling, Kubang Pasu, Langkawi, Kulim, Kuala Muda, Krian and the number of women working in the paddy fields was greater than the number of male planters. ${ }^{52}$

In 1930s, women's participation in paddy planting in the Malay Federated Malay States could be said to be almost equal in numbers with men. There are 33,588 Malay women who were involved in these activities while the number of men is 44.421 individuals. Of the total number of Malay women, they were largely concentrated in Perak and Pahang with a total number of 12.502 individuals and 13,092 individuals. While in Selangor the involvement of women in this activity was very low with a total of only 574 women in $1931 .{ }^{53}$

In the Unfederated Malay States, the number of Malay women who have been involved in the paddy field was 98.041 in 1931. Of these, the majority came from Kelantan with a total involvement of 40,070 women, followed by Kedah, 35,494; Terengganu, 14,577 and Perlis 7,900. For the state of Johor, Malay women's participation in these activities was very low for about $206 .{ }^{54}$

Other than fishing and paddy planting, the Malay women were also involved in rubber-based economic sectors. Due to the development of high rubber prices in the international market since 1924-1926, the demand for rubber in the Malay States was increasing. Women in Kedah were actively involved and turning their field work into rubber cultivation.

The involvement of women in economy was also discussed in 1930s in local newspapers such as Warta Malaya, Majlis, Lembaga Melayu, Bulan Melayu, Saudara etc. For example, Warta Malaya in the column entitled "Pelajaran dan Pekerjaan Anak-anak Perempuan Melayu" described the involvement of women in the economy. This column discussed the various jobs that women began to pursue in the 1930s. ${ }^{55}$ Although the sector may be considered as lightweight, it was a starting point for women to engage in broader economic activities.

However, the Malay women in the east coast were very different from other women in Malaya because they were more active in business. For example, the women in Kelantan had been actively involved in business activities, able to rent shops to sell items such as clothing and food in Kota Bharu. ${ }^{56}$ This was because they were involved in business activities for many generations. This could be seen through the statements made by Frank Swettenham:

\footnotetext{
${ }^{52}$ Mahani Musa (21-22 Ogos 2000), “Wanita Melayu Kedah dan Tanah, 1900-1940-an,” Working Paper of Seminar Kedah 100 Tahun, Kedah: Universiti Utara Malaysia.

${ }^{53}$ C.A. Vlieland, A Report on the 1931 Cencus, p. 288.

${ }^{54}$ C.A. Vlieland, A Report on the 1931 Cencus, p. 312.

${ }^{55}$ Please refer to "Pelajaran dan Pekerjaan Anak-anak Perempuan Melayu", Warta Malaya, 5 Mac 1938, p. 3.

${ }^{56}$ Please refer to Fail Kelantan 310/1939, berkenaan dengan hal kesulitan yang dihadapi oleh wanita Melayu di Pekan Kota Bharu Kelantan.
} 
The people of this place have certain peculiar customs of which it may mentioned that though they are Mohammadans. The women move about as freely as men. They mind the shops and deal with the customers. The weave the silk sarongs for which Kelantan is famous and they do as much carrying and marketing, gossiping and filed work as their father, husband, brothers and lovers. That is one striking peculiarity of the place. ${ }^{57}$

Women in Terengganu have dominated the textile industry for generations. In Terengganu, 3,976 Malay women were involved in this sector compared to 225 men in 1931. While in Kelantan, 1,238 Malay women were involved in the textile industry to 253 Malay men. ${ }^{58}$ In addition, some Terengganu women were involved in fishing activities. They dried seafood products for the salting process and some sold fresh marine products. These women were also well known for their ability in selling foods, betel leaves, fire woods, flowers, hand-made souvenirs and rearing chickens and ducks. ${ }^{59}$ Interestingly, there were some woman in the East Coast who were fishermen, but in terms of numbers, it was small compared to men. In the early 1920s a census showed that only 388 women in Terengganu were working as fishermen. ${ }^{60}$

Besides, the Malay women contributed to business as grocery shop owners, coffee house owners, cigarette wholesalers, and clothes and sarung suppliers. On the other hand, the women outnumbered the men in other economic sectors such as in vegetable growing, roof repair, sarung embroidery, tobacco making and many more. ${ }^{61}$

\section{Malay Women Contribution in the Health Aspect}

In 1920s, aspects of women's health started to be emphasized by the British in Malaya. This was because there were many cases of mother and infant deaths during or after childbirth. A Public Health Education Committee of the Federation States has produced a guideline on healthy lifestyle for women in Malaya. The booklet was translated by $\mathrm{Za}^{\prime} \mathrm{ba}^{62}$ in the Bulan Melayu (a magazine which was first published in 1930) for women to read especially the mother. They were suggested to have fresh air, perform physical exercises, eat healthy foods, drink plenty of plain water in order to have healthy baby and give birth in hospitals rather than at home. ${ }^{63}$

The main aspect emphasized by the government was on women and after their delivery. This was to ensure a high birth rate and reduce infant mortality. The District Officer of Selangor wrote on the various approaches to gain the confidence of expectant mothers to give birth with the aid of qualified midwife. They were also expected to regularly visit the clinics and hospitals for follow up checkups to ensure both mother and baby were in good health. In 1930s, the hospital provided guidance for future mothers on good nutritious diets, foods during confinement and the baby ${ }^{64}$ These efforts were essential to produce a good standard of health that would later contribute to the country's development in the long run.

Prior to the availability of trained midwives provided by the government, the women in labor seek help from the local village midwives. It was a custom practiced for generations by the Malays. However, some changes began in the 1930s when the government introduced several approaches by providing trained midwives to reduce infant mortality each year. Among the efforts made by the government were to provide training for midwives among Malays to replace Eurasian Nurses, introduce maternal and child health programs and improve the level of medical services in Malaya. According to the census in the Federated Malay States, there were 294 Malay women involved in health services in 1911. Of these, about 129 were in Perak, 69 in Selangor, 51 in Negeri Sembilan and 45 in Pahang. ${ }^{65}$ In Johor, women's

\footnotetext{
${ }^{57}$ Frank Swettenham (1948), British Malaya: An Account of the Origin and Progress of British Influence in Malaya, London: Allen \& Unwin, p. 169.

${ }^{58}$ C.A Vlieland, A Report on the 1931 Cencus, p. 313

${ }^{59}$ Kisah Pelayaran Muhammad Ibrahim Munsyi, p. 35.

60 J.E. Nathan (1921), The Cencus of British Malaya.

${ }^{61}$ Mahani Musa (2005), Sejarah Sosioekonomi Wanita Melayu Kedah, 1881-1940, Bangi: Universiti Kebangsaan Malaysia, pp. 109 \& 111.

62 Zainal Abidin bin Ahmad (Za'ba) was a writer and linguist from Linggi, Negeri Sembilan. He received his early education at a Malay school in Batu Kikir and continued his study at St. Paul's Institution Seremban. He has been a teacher in several schools and at the same time wrote a number of books, a series of monographs and articles that was later published in newspapers and magazines. Arba'iyah Mohd Noor (2000), "Pemikiran Pendidikan Za'ba," Purba, Vol. 19, p. 16-18.

${ }^{63}$ Za'ba (1930), "Kelebihan Duduk di Hospital," in Bulan Melayu, 1 July 1930, Vol. 2, p. 33.

${ }^{64}$ Federated Malay States Annual Report on the Social and Economic Progress of Selangor 1939.

${ }^{65}$ J.E. Nathan (1921), The Cencus of the Federated Malay States 1911, p. 143.
} 
participation in this field reached 104 in the early 1930s. ${ }^{66}$ In Kelantan, there were five Malay women involved in the nursing profession in the $1940 \mathrm{~s}$, then increased to 19 by the $1950 \mathrm{~s} .{ }^{67}$

Although the government has tried to introduce modern treatment but the practice was still difficult to be accepted by the Malays. The effort was met with a hostile attitude by the Malays unlike the Chinese who preferred to undergo modern treatments in the hospitals and clinics. Many Malay women still accepted the traditional midwives as relevant as compared to the modern ones. For example, in 1939, out of a total of 184 birth cases, 181 were managed by village midwives while only three were managed by government midwives. ${ }^{68}$ This shows that modern treatment was still doubted by the Malays as compared to other races in Malaya at that time.

Trained midwives by the government aimed to reduce infant mortality especially in the rural areas. These Malay women obtained their trainings in the government hospitals. They were later gradually posted to rural locations to replace the existing traditional midwives. For example in Perak, in 1938, there were 3,752 birth cases managed by government midwives and 2,572 cases in the following years. ${ }^{69}$ Although the number of trained midwives placed in villages in Perak decreased by 1,180 in 1939, it did not mean that trained midwives were not needed., It was due to the vacancy that had been filled up the previous year. These trained midwives were usually monitored by female medical officers.

In the Baby Health Centre of Kuala Lumpur, the female health officer was responsible to locate the midwives in the districts. They were selected based on the interviews and qualifications and no one was allowed to become a government midwife without going through the selection phase done by the female medical officer. ${ }^{70}$ In the Kuala Terengganu hospital in 1933, there were 44 treatments monitored by the government midwife as compared to only 34 cases in the year before. On the other hand, a total of 127 patients were treated in the mother and baby health clinic in 1933 as compared with only 117 people in 1932. Mother and baby health clinic in Kuala Terengganu were observed by the government. A total of 2807 cases were recorded with a total number of patients reaching 7854 people. ${ }^{71}$ On the other hand, the government also provided a mother and baby health center to educate them on healthy diets based from their way of living in the villages. The government faced quite a challenge in convincing the Malays on the modern medical methods that were more effective than the traditional practices. An emphasized was made on the method of regular treatment to ensure constant health was valued and preserved at all time. ${ }^{72}$

There were also efforts made by the government to provide dispensary and female medical officer in the rural areas to assist expecting mothers as well to provide medication after they were treated. Based on the files in the 1930s, there were records of the attention given by the government on the treatments especially to the expecting mothers. For example in Kedah in 1934, the Chief of Mukim Langgar was given the permission and assistance by the government to establish a hut with cement floor to be used by the female medical officer. ${ }^{73}$ The position of female medical officer was created to ensure that patients who could not be treated by male doctors would get proper treatments as well. ${ }^{74}$ This scenario later highlighted the women's importance in term of health and welfare. It is essential for mothers to stay healthy since their health condition will influence the children's health altogether.

\section{Malay Women in the Writing Activity}

The Malay women were already active in writing as early as the 19th century in Riau. Amongst those who had early awareness in this field were the children of Raja Ali Haji such as Raja Kalthum and Raja Safiah together with her son Raja Hasan. ${ }^{75}$ Raja Kalthum was said to have written a poem entitled

\footnotetext{
66 Ahmad Fawzi Basri (1988), Johor 1855-1917: Pentadbiran dan Perkembangan, Petaling Jaya: Penerbit Fajar Bakti, p. 41.

${ }^{67}$ Nik Zainab Abdul Karim (Karimah Zainab) (1975), Wanita Melayu dalam Konteks Perubahan Ekonomi dan Politik (Satu Kes Studi di Kota Bharu, Tesis Sarjana, Fakulti Sastera dan Sains Sosial, Universiti Malaya, p. 115.

68 Nik Zainab Abdul Karim (1975), Wanita Melayu dalam Konteks Perubahan Ekonomi dan Politik, p. 115.

${ }^{69}$ Annual Report Social and Economic Progress of the People of Perak 1939.

${ }^{70}$ Federated Malay States Annual Report on the Social and Economic Progress of the People of Selangor 1932.

${ }^{71}$ Annual Report Social and Economis Progress Trengganu 1933.

72 Federated Malay States Annual Report on the Social and Economic Progress of Selangor 1939.

${ }^{73}$ File 2855-1353, Accomodation for Malay Women and Children Dispensary at Langgar.

${ }^{74}$ Annual Report on the Social and Economic progress of the People of Negeri Sembilan 1932.

${ }^{75}$ Raja Hasan wrote a poem entitled Syair Burung. Abu Hassan Sham (1995), Syair-syair Melayu Riau, Kuala Lumpur: Perpustakaan Negara Malaysia, appendix E.
} 
Syair Saudagar Bodoh and Raja Safiah wrote a poem entitled Syair Kumbang Mengindera. ${ }^{76}$ Even though the Riau government was facing its downfall in the late 19th century, the writing activity remained active. Through the establishment of Rusydiah Club $^{77}$ in 1892, there were many Malay writings in various disciplines such as fiction, religion, history and many more. Besides politics, the club also included other aspects such as economy, social and literary activities. Translations and writings that were done as a group or individually were part of the activity. ${ }^{78}$ This club inspired the women to write actively. Early 20th century witnessed the rise of women in the writing arena as a continuation of their struggle in this activity. A great female figure who contributed to the early establishment of the said interest was Raja Aishah Sulaiman who was the grandchild of Raja Ali Haji and a wife to Raja Khalid Hitam. Her great writings included Hikayat Shamsul Anuar and Syair Khadamuddin. ${ }^{79}$ Both works were classified as fictional autobiography that was formed based on the author's emotion and ideas toward a certain issue. After the downfall of the Riau empire in 1911, there were more female writers who produced Malay literary works such as Khadijah Terung's Perhimpunan Gunawan bagi Laki-laki dan Perempuan, ${ }^{80}$ Raja Badriah Muhammad Tahir's Adab al-Futat, ${ }^{81}$ Encik Kamariah's Syair Sultan Mahmud di Lingga ${ }^{82}$ and many others. ${ }^{83}$

Besides authors from Riau, there were other authors who appeared in Malaya in the early 20th century. For example, there were some royal women who were involved in the field of writing such as Tengku Ampuan Mariam (wife of Sultan Sulaiman,Terengganu), Tengku Dalam Kalthum (granddaughter of Sultan Zainal Abidin III, Terengganu) and Raja Perempuan Ta'ayah binti Raja Abdul Hamid (wife of Sultan Yussoff Izzuddin Syah Perak). Tengku Ampuan Mariam wrote about Salsilah dari al-Marhum Baginda Umar Hingga kepada al-Marhum Sultan Sulaiman serta Lain-lainnya Lawatan serta Tarikh Pelayaran ke Jawa dan Lain-lainnya ke Mekah which was also known as Salasilah Sultan Omar. ${ }^{84}$ The writing was a brief diary notes on several happenings in Terengganu during the reign of her husband, Sultan Sulaiman Badrul Alam Shah as well as information on the Terengganu and Pahang ancestors. Although it was brief, this manuscript provided important information through the author's observation and witnessed some of the events that took place during that time. ${ }^{85}$ Tengku Dalam Kalthum wrote about the reign of Sultan Zainal Abidin III in Syair Sultan Zainal Abidin III (1936), Khatim, Syarif'ul-Akhtar, Syamsul Anwar, Syah Kobat, Kobat Syahar Zaman, Kobat Syah Riar, Gharib, Hayat ul-Nasib, Cik Siti Lela, Asyik and Koran. ${ }^{86}$ Meanwhile, Raja Perempuan Ta'ayah did not directly write the work but gave instructions to Arshad bin Ismail to copy three manuscripts. It implies an impression of her interest in writing. Among the manuscripts were Hikayat Panji, Hikayat Shah Kobat Lela Mengindera and Hikayat Sharif al-Akhtar wa Shuhtun Nahar. ${ }^{87}$

\footnotetext{
${ }^{76}$ Abu Hassan Sham, Syair-syair Melayu Riau.

77 The word Rusydiah derived from the word Rusd meaning 'path' or 'te right path'. This group at first started among the royal family Musyawarah member led by the Sultan of Riau but later expanded into a club. The club was established by the ministers, Muslim scholars and thinkers of Riau-Lingga aimed at preserving the dignity of the Riau community. The leader was Tengku Besar (Tengku Umar) who led the people to voice out their dissatisfaction toward the Dutch policy on Riau-Lingga especially after they forced Sultan Abdul Rahman Mu'azzam Syah (1884-1911) to sign an agreement on $18^{\text {th }}$ May 1905 . Besides politics, the club also included other aspects such as economy, social and literary activities. Translations and writings that were done as a group or individually were part of the activity. UU. Hamidy (1981), Riau sebagai Pusat Bahasa dan Kebudayaan Melayu, Pekan Baru: Bumi Pustaka, p. 27; Abu Hassan Sham (1987), "Karya-karya yang Berlatarbelakangkan Islam dari Pengarang Melayu Riau-Johor Sehingga Awal Abad Kedua Puluh,” in Zahrah Ibrahim (ed.), Tradisi JohorRiau, Kertas kerja Hari Sastera 1983, Kuala Lumpur: Dewan Bahasa dan Pustaka, p. 260. Refer also to Abu Hassan Sham (1983), "Rusydiah Kelab dan Taman Penghiburan," Purba, Vol. 2, p. 39; Virginia H Matheson (1991), Tuhfat al-Nafis: Sejarah Melayu-Islam, Kuala Lumpur: Dewan Bahasa dan Pustaka, p. 9; Hasan Junus \& UU. Hamidy, "Sumbangan dan Peranan Cendiakawan Riau dalam Penghidupan Kebudayaan Nasional Indonesia," in Tradisi Johor-Riau, pp. 13 and 141; Timothy P. Barnard (1994), "Taman Penghiburan: Entertainment and the Riau Elite in the Late $19^{\text {th }}$ Century," MBRAS, Vol. LXVII, no. 2, p. 27.

${ }^{78}$ UU. Hamidy (1981), Riau sebagai Pusat Bahasa dan Kebudayaan Melayu, p. 27; Timothy P. Barnard (1994), "Taman Penghiburan: Entertainment and the Riau Elite in the Late 19 ${ }^{\text {th }}$ Century," p. 27.

${ }^{79}$ Ding Choo Ming (1999), Raja Aisyah Sulaiman Pengarang Ulung Wanita Melayu, Bangi: Universiti Kebangsaan Malaysia, p. 131.

${ }^{80} \mathrm{He}$ wrote on sex guide entitled Perhimpunan Gunawan bagi Laki-laki dan Perempuan in 1911. Abu Hassan Sham (1995), Syair-syair Melayu Riau, p. 356.

${ }^{81}$ He wrote a guidance book entitled Adab al-Futat in 1925. Abu Hassan Sham (1995), Syair-syair Melayu Riau, p. 357.

${ }^{82}$ Encik Kamariah was the governess to Sultan Mahmud Muzaffar Shah at Lingga and wrote a poem entitled Sultan Mahmud di Lingga. The content contradicted with the ones stated in Tuhfat al-Nafis since it portrayed the ruler as just but in actual scene, he was stubborn, often in conflict with the ministers and a womanizer in Singapore. Ibid., pp. 56-57.

${ }^{83}$ Abu Hassan Sham (1995), Syair-syair Melayu Riau, pp. 356-357.

${ }^{84}$ A short-formed manuscript of Salasilah Sultan Omar.

85 Salasilah Sultan Omar, Museum of Terengganu (undated, unpublished and still in jawi scripts)

${ }^{86}$ Arba'iyah Mohd Noor (2011), “Tengku Dalam Kalthum Binti Tengku Wok Khazaki,” working paper, Seminar Tokoh Pujangga Silam, Organized by DBP, Kuala Lumpur, September 21-22.

87 Jelani Harun (2011), Umpama Sebuah Bahtera: Kajian Naskhah Melayu Sejarah Kesultanan Negeri Perak, Kuala Lumpur: Arkib Negara Malaysia, p. 80.
} 
At the same time, there were also newspapers based on the minds of the Malay intellectuals as a medium to reinforce the writing activity in Malaya. For example, Jawi Peranakan and Bintang Timor that emerged at the end of the 19th century, followed by the publication of al-Imam (1906-1908), Saudara, Utusan Melayu (1939), Warta Malaya (1930), al-Ikhwan, Utusan Zaman, al-Hikmah, Majlis (1934) and Bulan Melayu (1930). ${ }^{88}$

In the midst of its publication on the issues related to the Malay society in 1930s, Ibu Zain created awareness about the backwardness of Malay women in various fields. Through few columns in magazines and newspaper such as Majalah Guru, Lembaran Guru and Bulan Melayu, she asked the Malay teachers to educate the public so that they could go further and compete with other nations in various fields. ${ }^{89}$ Besides, there were several female writers who were active in writing activities such as Wok binti Abdullah and Mardhiah Haji Zainuddin. Wok binti Abdullah encouraged Kelantanese women to come forward and take the example of women from Johor and Seberang (Indonesia) who have been involved in various jobs and urged the government to provide training in employment to prevent women from getting involved in unprofessional activities. ${ }^{90}$ Meanwhile, Mardhiah bt. Haji Zainuddin was a regular contributor on the ideas included in the Utusan Zaman newspaper. The topic on motherhood became the main focus in her writings. Among the issues discussed were Kaum Ibu Sebelum Masuk di dalam Pergaulan (Mothers before socializing), ${ }^{91}$ Tukangan Anak Perempuan Melayu di dalam Sekolahnya (The role of female students in the schools), ${ }^{92}$ Kaum Ibu Dengan Suratkhabar (Mothers and newspapers) ${ }^{93}$ and Kaum Ibu Dibebaskan Pelajarannya Sebagai Lelaki (Mothers to be given the freedom to study like the men). ${ }^{94}$ These topics were meant to expose the actual situations faced by the Malay women at that time that differed from the other races who embraced development from the education, health, economy and job aspects.

Japanese occupation in Malaya from 1942 to 1945 did not prevent the Malay women to continue in writing activities. The evidence can be seen in Ibu Zain and Rohana Djamil's writings in the Fajar Asia newspaper (Barisan Puteri column). Moreover, Mas Neng (also known as Mas Nurafisah Neng, Norasmara and Asmara Yatim) was also a contributor in this newspaper as well as some other magazines, such as Pancaran Pena, Juita, Cerita, Kenchana, Suara Johor, Pembuka Selera (Malay Press) and Merdeka (akhbar UMNO). ${ }^{95}$ At the same time the Matahari Memancar, a new magazine was published in Johor by Siti Nurani Janain. Both magazines had played an important role in encouraging women to engage in the women organization, economic and educational sectors.

Besides newspaper and magazine, the Malay women were also involved in creative writing (short stories). In the 1940s, several figures of modern Malay literature, such as Azizah (Doktor Mahmud) in Mastika magazine, Kalsom Haji Saadun (Gugurnya Kembang Melati), Adibah Amin (Ibu Tirikah Yang Kejam) etc. ${ }^{96}$ In the 1950 s, many talented women were involved in writing activities such as Anis Sabirin, Sawiah Hassan, Salmi Manja, Zawiah Md. Noh and Zaharah Nawawi. ${ }^{97}$

This discussion shows that the role of Malay women has changed over the years. Generally, these writers had tried to make women aware of the progress in all fields. Although there were many female writers, their involvement was still far behind compared to men. In the 1970s, the lack of women writers was still highlighted in the local newspapers. This was because some of them, had to carry out household responsibilities; meanwhile, the educated female writers were responsible for their duties as teachers, clerks, government officers etc. After getting married, their responsibility grew bigger and the focus on writing became limited or forgotten. ${ }^{98}$ This was the obstacle that was endured by the Malay women in writings.

\footnotetext{
${ }^{88}$ Masliah Salleh (1998/1999), Utusan Melayu: Sumbangannya Kepada Orang Melayu Dari 1939-1946, Latihan Ilmiah, Jabatan Sejarah Universiti Malaya, pp. 15-19.

${ }^{89}$ Ibu Zain's writing about the independence of Malaya had included in Bulan Melayu, volume 33, 1957. Bulan Melayu, Vol. 33 (August 1957), p. 266-267.

${ }^{90}$ Kenchana, vol.5, (August 1930), pp. 109-112.

91 Utusan Zaman, (21st January 1940).

${ }^{92}$ Utusan Zaman, ( 31st December 1939).

${ }^{93}$ Utusan Zaman, (10th December 1939).

${ }^{94}$ Utusan Zaman, (February 1940).

${ }^{95}$ Mahani Musa, "Sumbangan Wanita Melayu dalam Kegiatan Persuratkhabaran dan Majalah di Malaysia, Tahun 1920-an -1960-an," p. 78.

${ }^{96}$ Raja Mashitah Raja Ariffin and Siti Aisah Murad (1991), "Kajian Mengenai Wanita dan Penulisan di Dewan Bahasa dan Pustaka," working paper, Diskusi Sehari Pengkajian Wanita Malaysia, Arkib Negara Malaysia, 25 February, p. 6.

${ }_{97}$ Mahani Musa, "Sumbangan Wanita Melayu dalam Kegiatan Persuratkhabaran dan Majalah di Malaysia, Tahun 1920-an -1960-an,” p. 78.

98 Cenderamata, (December 1973).
} 


\section{Conclusion}

The beginning of the 20th century was a turning point for Malay women's involvement in various aspects of development. At this point, the role of women was not only as a housewife but they were also involved in various fields. Education managed to uplift the standard of the Malay women to a higher degree. Formal education that they received had enlightened them to change the status and lifestyle of the Malays. In politics, educated women were getting involved in organizational activities. This was the first step for Malay women to get active in the political arena. They were the main catalyst for state unions as well as the establishment of Persatuan Kaum Ibu UMNO. This involvement eventually led to a greater change when women experienced not only changes in appearances, but they were also engaged in economic and social aspects after World War II.

Acknowledgement: We would like to acknowledge the financial support provided by the University of Malaya under the Equitable Society Research Cluster (ESRC) research grant RP012A-13SBS and under Faculty Grant GPF016J-2018.

\section{References}

\section{Primary Sources}

\section{a. File/ English Records/Annual Reports}

Annual Report on Education in Straits Settlement and the Federated Malay States 1937

Annual Report on the Social and Economic progress of the People of Negeri Sembilan 1932.

Annual Report Social and Economis Progress Trengganu 1933.

Annual Report Social and Economic Progress of the People of Perak 1939.

CPR.K 17/95, no 1A. Documentary on Aishah Ghani, National Archieve of Malaysia.

CPR.V. 22/95. Documentary on Aishah Ghani. National Archieve of Malaysia.

Fail Kelantan 310/1939, berkenaan dengan hal kesulitan yang dihadapi oleh wanita Melayu di Pekan Kota Bharu Kelantan.

Federated Malay States Annual Report on the Social and Economic Progress of the People of Selangor 1932.

Federated Malay States Annual Report on the Social and Economic Progress of Selangor 1939.

File 2855-1353, Accomodation for Malay Women and Children Dispensary at Langgar.

Nathan J.E. (1921), The Cencus of British Malaya.

Vlieland C.A, A Report on the 1931 Cencus.

\section{b. Malay Manuscripts}

Salasilah Sultan Omar, Museum of Terengganu (undated, unpublished and still in jawi scripts)

Muda, Asaad Shukri, Riwayat Kelantan, Manuscript was transliterated by Zahir Ahmad. (undated and unpublished) 
Journal of Al-Tamaddun, Vol. 15 (1), 2020, 67-84

c. Newspaper and Magazine

al-Imam (Issue 1, Vol. 6, 18 December 1906).

al-Imam (Issue 6, 6 December 1906).

Bahtera (26 April 1932)

Bulan Melayu (January 1930)

Bulan Melayu (June 1930)

Bulan Melayu (July 1930)

Cenderamata, (December 1973)

Kenchana (vol.5 August 1930)

Majlis, (1 ${ }^{\text {st }}$ December 1934)

Utusan Zaman, (10, 17, 31 December 1939, 21st January 1940 and February 1940)

Warta Malaya (5 Mac 1938)

\section{d. Interview}

Interview with Tan Sri Aishah Ghani on the $27^{\text {th }}$ January 2006, Kampung Baru Kuala Lumpur.

\section{Secondary Sources}

Abdul Kadir Munsyi, Abdullah (1974), Hikayat Abdullah, Kuala Lumpur: Dewan Bahasa dan Pustaka.

Abdul Karim Nik Zainab (Karimah Zainab) (1975), Wanita Melayu dalam Konteks Perubahan Ekonomi dan Politik (Satu Kes Studi di Kota Bharu), Tesis Sarjana, Fakulti Sastera dan Sains Sosial, Universiti Malaya.

Abu Bakar, Shafie (1989), "Kitab al-Durr al-Manzum and Kitab al-Luma' Sebagai Pancaran Budaya Ilmu di Melaka: Permasalahan dan Pengaruh Lanjutannya," working paper, International Conference of Malay Studies, University of Malaya, Kuala Lumpur.

Adam, Ramlah (1978), UMNO Organisasi dan Kegiatan Politik, Kuala Lumpur: Mohd Nawi Book Store.

Adam, Ramlah (1994), Ahmad Boestamam: Satu Biografi Politik, Kuala Lumpur: Dewan Bahasa dan Pustaka, 1994.

Ahmad, A.Samad (romanized) (1996), Sulalatus Salatin-Sejarah Melayu, Kuala Lumpur: Dewan Bahasa dan Pustaka.

Ariffin Jamilah (1992), Women and Development in Malaysia, Selangor: Pelanduk Publication.

Bardwick J. M. (1971), Psychology of Women: A Study of Bio-Cultural Conflicts, New York: Harper and Row.

Barnard, Timothy P. (1994), "Taman Penghiburan: Entertainment and the Riau Elite in the Late $19^{\text {th }}$ Century," MBRAS, Vol. LXVII, no. 2.

Basri, Ahmad Fawzi (1988), Johor 1855-1917: Pentadbiran dan Perkembangan, Petaling Jaya: Penerbit Fajar Bakti

Choo Ming, Ding (1999), Raja Aisyah Sulaiman Pengarang Ulung Wanita Melayu, Bangi: Universiti Kebangsaan Malaysia.

Dancz, Virginia H (1987), Women and Party Politics in Peninsular Malaysia, Singapore: Oxford University Press.

Fakeh, Shamsiah (2007), Memoir Shamsiah Fakeh: Dari Awas ke Regimen ke-10, Petaling Jaya: SIRD. 
The Transition of Malay Women's Role and Contribution in the Early 20th Century

Ghani, Aishah (1993), "Peranan Wanita UMNO dalam Politik Kebangsaan," in UMNO Dalam Arus Perdana Politik Kebangsaan, Kuala Lumpur: Mahir Publications.

Hamidy, U. U. (1981), Riau sebagai Pusat Bahasa dan Kebudayaan Melayu, Pekan Baru: Bumi Pustaka.

Harun Jelani (2011), Umpama Sebuah Bahtera: Kajian Naskhah Melayu Sejarah Kesultanan Negeri Perak, Kuala Lumpur: Arkib Negara Malaysia.

Harun Jelani (ed.) (2004), Bustan al-Salatin, Kuala Lumpur: Dewan Bahasa dan Pustaka.

Hussain, Abdullah dan M. Hussain, Khalid (2000), Pendeta Za'ba dalam Kenangan. Kuala Lumpur: Dewan Bahasa dan Pustaka.

Ibrahim, Zahrah (ed.) (1987), Tradisi Johor-Riau, Kertas kerja Hari Sastera 1983, Kuala Lumpur: Dewan Bahasa dan Pustaka.

Ismail, Abdul Rahman (romanized) (1998), Sejarah Melayu-The Malay Annals, MS. Raffles No.18, Kuala Lumpur: MBRAS.

Kaur, Amarjit (January 1989), "An Historical Analysis of Women's Economic Participation in Development," Paper presented at the Colloquium on Women and Development-Implication for Planning and Population Dynamics, University of Malaya

Kay Kim, Khoo (ed.) (1985), Sejarah Masyarakat Melayu Moden, Kuala Lumpur: Jabatan Penerbitan Universiti Malaya.

Lamry, Mohamed Salleh (2011), Siti Norkiah Mahmud: Srikandi dari Pahang Utara, Petaling Jaya: SIRD.

Manderson, Lenore (1980), Women, Politics and Change: The Kaum Ibu UMNO, Malaysia, 19451972 Kuala Lumpur: Oxford University Press

Manderson, Lenore (1981), Wanita, Politik dan Perubahan Pergerakan Kaum Ibu UMNO, Malaysia, 1945-1972, translated by Samsudin Jaapar, Kuala Lumpur: Fajar Bakti.

Mat Enh, Azlizan and Abdul Ghani, Rohani eds. (2012), Wanita dan Masyarakat, Batu Pahat: UTHM.

Mohd Noor, Arba'iyah (2011), "Tengku Dalam Kalthum Binti Tengku Wok Khazaki," working paper, Seminar Tokoh Pujangga Silam, organized by DBP, Kuala Lumpur, September 21-22.

Mohd Noor, Arba’iyah (2000), “Pemikiran Pendidikan Za’ba,” Purba, Vol. 19.

Musa, Mahani (2005), Sejarah Sosioekonomi Wanita Melayu Kedah, 1881-1940, Bangi: Universiti Kebangsaan Malaysia.

Musa, Mahani (21-22 August 2000), "Wanita Melayu Kedah dan Tanah, 1900-1940-an,” working paper, Seminar Kedah 100 Tahun, Universiti Utara Malaysia.

Othman, Mohd Fadzil (1980), Kisah Pelayaran Muhammad Ibrahim Munsyi, Kuala Lumpur: Dewan Bahasa dan Pustaka.

Pergerakan Kaum Ibu UMNO: Sejarah dan Kejayaan-kejayaannya, Kuala Lumpur: Bahagian Penyelidik Ibu Pejabat UMNO Malaysia, (no author and undated)

Phelps, S. and Austin, N. (1975), The Assertive Woman, California: IMPACT. 
Journal of Al-Tamaddun, Vol. 15 (1), 2020, 67-84

Rahim, Ab. Halim and Wan Daud, Balkis (1992), Pandu Puteri Malaysia, Kuala Lumpur: Dewan Bahasa dan Pustaka.

Raja Ariffin, Raja Mashitah \& Murad, Siti Aisah (1991), "Kajian Mengenai Wanita dan Penulisan di Dewan Bahasa dan Pustaka," working paper, Diskusi Sehari Pengkajian Wanita Malaysia, Arkib Negara Malaysia, 25 February.

Ryan, N.J (1959), Malaya Through Four Centuries an Anthology 1500-1900, London: Oxford University Press.

Saat, Ishak \& Zainun, Nazarudin (eds.) (2011), Wanita dan Perjuangan, Batu Pahat: UTHM.

Salleh, Masliah (1998/1999), Utusan Melayu: Sumbangannya Kepada Orang Melayu Dari 1939-1946, Latihan Ilmiah, Jabatan Sejarah Universiti Malaya.

Sham, Abu Hassan (1983), "Rusydiah Kelab dan Taman Penghiburan,” Purba, Vol. 2.

Sham, Abu Hassan (1995), Syair-syair Melayu Riau, Kuala Lumpur: Perpustakaan Negara Malaysia, appendix E.

Sulaiman, Adibah et. al. (2011), "Syed Shaykh Ahmad Alhady: A Religious Education Reformist in the Late 19 and Early 20 Century," Middle-East Journal of Scientific Research, Vol. 7, Special Issue of Diversity of Knowledge on Middle East.

Swettenham Frank, (1948), British Malaya: An Account of the Origin and Progress of British Influence in Malaya, London: Allen \& Unwin.

Virginia, Matheson H. (1991), Tuhfat al-Nafis: Sejarah Melayu-Islam, Kuala Lumpur: Dewan Bahasa dan Pustaka.

Wan Ali, Wan Muhammad (1973), Suntingan dan Anotasi Sebuah Kitab Tasawwuf Melayu Kurun Ketiga Belas Hijrah/ Kedelapan Belas Masihi: ad-Durru'n-Nafis, MA Thesis, Institute of Language, Literature and Culture, Kuala Lumpur: National University of Malaysia. 